\title{
Chromatin Architecture as an Essential Determinant of Dendritic Cell Function
}

\author{
Giselle M. Boukhaled ${ }^{1 \dagger}$, Mario Corrado ${ }^{1 \dagger}$, Hannah Guak ${ }^{1 \dagger}$ and Connie M. Krawczyk ${ }^{1,2 *}$ \\ ' Department of Physiology, Goodman Cancer Research Center, McGill University, Montreal, QC, Canada, ${ }^{2}$ Center for Cancer \\ and Cell Biology, Program in Metabolic and Nutritional Programming, Van Andel Institute, Grand Rapids, MI, United States
}

OPEN ACCESS

Edited by:

Fabiola Osorio

Universidad de Chile, Chile

Reviewed by:

Susan Kovats,

Oklahoma Medical Research

Foundation, United States

Timothy M. Johanson,

Walter and Eliza Hall Institute of

Medical Research, Australia

*Correspondence:

Connie M. Krawczyk

connie.krawczyk@vai.org

tThese authors have contributed equally to this work

Specialty section:

This article was submitted to Antigen Presenting Cell Biology,

a section of the journal

Frontiers in Immunology

Received: 16 October 2018 Accepted: 02 May 2019

Published: 04 June 2019

Citation:

Boukhaled GM, Corrado M, Guak H and Krawczyk CM (2019) Chromatin

Architecture as an Essential

Determinant of Dendritic Cell Function.

Front. Immunol. 10:1119.

doi: 10.3389/fimmu.2019.01119
Epigenetics has widespread implications in a variety of cellular processes ranging from cell identity and specification, to cellular adaptation to environmental stimuli. While typically associated with heritable changes in gene expression, epigenetic mechanisms are now appreciated to regulate dynamic changes in gene expression-even in post-mitotic cells. Cells of the innate immune system, including dendritic cells (DC), rapidly integrate signals from their microenvironment and respond accordingly, undergoing massive changes in transcriptional programming. This dynamic transcriptional reprogramming relies on epigenetic changes mediated by numerous enzymes and their substrates. This review highlights our current understanding of epigenetic regulation of DC function. Epigenetic mechanisms contribute to the maintenance of the steady state and are important for precise responses to proinflammatory stimuli. Interdependence between epigenetic modifications and the delicate balance of metabolites present another layer of complexity. In addition, dynamic regulation of the expression of proteins that modify chromatin architecture in DCs significantly impacts DC function. Environmental factors, including inflammation, aging, chemicals, nutrients, and lipid mediators, are increasingly appreciated to affect the epigenome in DCs, and, in doing so, regulate host immunity. Our understanding of how epigenetic mechanisms regulate DC function is in its infancy, and it must be expanded in order to discern the mechanisms underlying the balance between health and disease states.

Keywords: dendritic cells, epigenetics (MeSH), metabolism, inflammation, tolerance, microenvironment

\section{INTRODUCTION}

Epigenetics refers to the regulation of gene expression by mechanisms other than changes in DNA sequence. Epigenetic mechanisms enable long-term phenotypic responses to the environment in the absence of initiating stimuli. Historically, epigenetic memory has referred to stable changes that are maintained through cell division. However, it is increasingly appreciated that dynamic changes in the epigenome, including in the absence of cell division, are equally important for proper cellular function.

Dendritic cells (DCs) are phagocytic cells of the innate immune system that reside in nearly every tissue and specialize in antigen presentation. They are rapidly responsive to stimuli including infection, inflammation, cancer, particles and cellular damage, are highly migratory, and direct the nature of ensuing immune responses by producing context-specific factors such as cytokines. As 
for most cells, epigenetic mechanisms underpin lineage specification of DCs. There are several subsets of DCs, all of which are derived from a common DC progenitor (CDP). CDPs give rise to plasmacytoid DCs (pDCs) and pre-DCs, the latter of which differentiates into conventional DCs ( $\mathrm{cDC} 1 \mathrm{~s}$ and $\mathrm{cDC} 2 \mathrm{~s}$ ) in secondary lymphoid tissues (1-6). pDCs produce high levels of type 1 interferons (IFNs) during antiviral and anti-tumor responses. cDCs are highly-specialized antigen-presenting cells; cDC1s $\left(\mathrm{XCR}^{+}\right)$specialize in antigen cross-presentation and stimulation of $\mathrm{CD}^{+} \mathrm{T}$ cells and $\mathrm{Th} 1$ responses, whereas cDC2s $\left(\mathrm{CD}_{11 \mathrm{~b}^{+}} \mathrm{CD} 172 \mathrm{a}^{+}\right)$specialize in antigen presentation to $\mathrm{CD} 4^{+} \mathrm{T}$ cells and direct responses to extracellular pathogens (7-10). Additionally, during active inflammation, monocytes can acquire the function of macrophages or DCs (moDCs) (8). The transcriptional mechanisms controlling lineage commitment and DC diversity have been extensively studied. Lineage-determining factors such as PU.1 and C/EBP are significant regulators of myeloid cell differentiation. They facilitate lineage specification of hematopoietic cells by forming stable interactions with their chromatin substrates, enabling secondary factors to drive lineage-specific gene expression (11-14). The complexity of lineage-determining factors and their roles in specifying DC fate through regulation of chromatin remodeling and gene expression have been described elsewhere and is not addressed here $(15,16)$.

DCs are relatively rare, and thus a number of in vitro culture systems have been developed to study their function (17). While the cells generated in these cultures do not perfectly reflect cells found in vivo, their experimental use has significantly advanced our knowledge of DC biology. Human DC cultures are typically monocyte-derived and generated by culturing blood monocytes with GM-CSF and IL-4 (18). For mouse, bone marrow can be cultured with combinations of GM-CSF with or without IL-4 to give rise to heterogeneous cultures of bone marrow-derived DCs (BMDCs) that possess CDC- and macrophage-like qualities (19-22). Culturing bone marrow with FLT3L gives rise to a mixed culture containing both cDC- and pDC-like cells (23-26). More recently, the addition of Notch-ligands to the in vitro culture system gives rise to cells that are more phenotypically similar to $\mathrm{CDC} 1 \mathrm{~s}$ and $\mathrm{CDC} 2 \mathrm{~s}$ (27). Because of the ease of generating BMDCs and the feasibility of generating large numbers of cells, BMDCs are frequently used for biochemical studies, including those addressing epigenetic and metabolic mechanisms.

Further to differentiation, dynamic epigenetic regulation is inherent to the massive transcriptional reprogramming required to orchestrate an effective and efficient immune response (28-31). In steady-state BMDCs, transcription factors (TFs), including ATF3, IRF4, and JUNB, were discovered to serve as priming factors for genes that are rapidly induced following TLR stimulation (11). Priming factors are present at accessible promoters and enhancers in the absence of stimulation. Upon stimulation, priming factors facilitate induced gene expression, possibly by serving as docking sites for dynamic factors or by maintaining chromatin accessibility of regulatory elements for other factors $(11,32)$. Epigenetic regulation of gene expression is also important for communicating context. Context is inferred by cell surface receptors such as pattern recognition receptors
(PRRs) and cytokine/chemokine/nutrient receptors, which detect environmental stimuli. Downstream of such receptors, receptorspecific signal transduction pathways lead to the activation of dynamic TFs, including EGR1, EGR2, NF- $\kappa$ B, and STATs, to mediate context-specific gene expression reprogramming $(11,15$, $28,32,33)$. For example, lipopolysaccharide (LPS) stimulation of DCs leads to a signaling cascade downstream of Tolllike receptor 4 (TLR4) that results in NF- $\kappa \mathrm{B}$ activation and translocation into the nucleus. NF- $\kappa \mathrm{B}$ activates the transcription of thousands of LPS-response genes necessary to orchestrate inflammation (22). Similarly, type I IFNs stimulate STAT1 activation through their receptor, IFNAR. IFNAR activation leads to the activation of interferon signaling genes (ISGs) that include antiviral response genes (34). The ability of these coordinated networks of transcription factors to drive programs of gene expression is intimately linked to the accessibility to regulatory regions such as enhancers and promoters, which is determined by the chromatin landscape.

Integration of context-specific gene expression into epigenetic memory is necessary for DCs to communicate context to other cells once they have migrated away from the site of initial stimulation. The extent to which dynamic changes occurring in the chromatin landscape following stimulation remain stable in rapidly responding, short-lived immune cells such as DCs is not well-understood. While activating TF networks are relatively well-studied in DCs, less is known about the impact of chromatin modifying factors on DC function. Here, we discuss epigenetic mechanisms that have been implicated in the regulation of DC biology, with emphasis on function over differentiation.

\section{EPIGENETIC MODIFICATIONS}

DNA methylation, histone modifications and chromatin accessibility are the most well-studied mechanisms that regulate gene expression (35-37). Implicated regulatory proteins are known as "readers," "writers," or "erasers" that detect, deposit or remove histone modifications, respectively. Histone modifications and associated regulatory proteins are continually being identified and our understanding of the mechanisms by which they regulate gene expression are continually refined [Table 1; $(44,45)$ ]. ATAC-seq, (Assay for Transposase Accessible Chromatin coupled to sequencing) gives an overall picture of chromatin accessibility irrespective of specific modifications and can be performed on few cells (46). Recently, a fairly comprehensive atlas of chromatin accessibility of 86 immune cells, including 5 DC subsets, was reported (47). These data provide key insights to the overall differences in the chromatin landscape among immune cells and serve as a foundation to more extensively study the mechanisms underlying the diverse and dynamic chromatin architecture in immune cells.

\section{DNA Methylation}

DNA methylation of cytosine residues (5-methylcytosine; $5 \mathrm{mC}$ ) occurs in the context of $\mathrm{CpG}$ dinucleotides and is mediated by the family of DNA methyltransferases (DNMTs) (36, 48, 49). Sites of DNA methylation are relatively stable, and are propagated through DNA replication during cell division. 
TABLE 1 | Enzymes mediating epigenetic modifications.

\begin{tabular}{|c|c|c|c|}
\hline Enzyme family & Examples & Catalyzed residue(s)* $^{*}$ & $\begin{array}{l}\text { Transcriptional } \\
\text { response }\end{array}$ \\
\hline \multirow{3}{*}{$\begin{array}{l}\text { DNA } \\
\text { Methyltransferase } \\
\text { (DNMT) }\end{array}$} & DNMT1 & Cytosine & $\begin{array}{l}\text { Repression } \\
\text { (Activation) }\end{array}$ \\
\hline & DNMT3a & & \\
\hline & DNMT3b & & \\
\hline DNA Demethylase & TET1-3 & 5-methylcytosine $(5 \mathrm{mC})^{\star \star}$ & Activation \\
\hline \multirow{7}{*}{$\begin{array}{l}\text { Histone } \\
\text { Deacetylase } \\
\text { (HDAC) }\end{array}$} & HDAC1-11 & $\begin{array}{l}\text { K residues, specificity } \\
\text { unknown }\end{array}$ & Repression \\
\hline & SIRT1 & $\begin{array}{l}\text { H1K26; H3K9, K14, K56; } \\
\text { H4K16 }\end{array}$ & \\
\hline & SIRT2 & H3K56; H4K16 & \\
\hline & SIRT3 & $\mathrm{H} 4 \mathrm{~K} 16$ & \\
\hline & SIRT4-5 & None & \\
\hline & SIRT6 & H3K9, K56 & \\
\hline & SIRT7 & H3K18 & \\
\hline \multirow{11}{*}{$\begin{array}{l}\text { Histone } \\
\text { Acetyltransferase } \\
\text { (HAT) }\end{array}$} & HAT1 & H2AK5; H4K5, H4K12 & Activation \\
\hline & p300 & $\begin{array}{l}\text { H2AK5; H2BK5, K12, K15, } \\
\text { K2O; H3K9, K14, K18, K23, } \\
\text { K27; H4K5 }\end{array}$ & \\
\hline & $\mathrm{CBP}$ & $\begin{array}{l}\text { H2AK5; H2BK12, K15; } \\
\text { H3K18, K23, K27 }\end{array}$ & \\
\hline & hGCN5 & $\mathrm{H} 3 \mathrm{~K} 9, \mathrm{~K} 14, \mathrm{~K} 18, \mathrm{~K} 23$ & \\
\hline & Tip60 & H2AK5, H3K14, H4K5 & \\
\hline & PCAF & $\mathrm{H} 3 \mathrm{~K} 14$ & \\
\hline & SRC-1 & $\mathrm{H} 3 \mathrm{~K} 9, \mathrm{~K} 14$ & \\
\hline & OGA & H3K14 & \\
\hline & CLOCK & $\mathrm{H} 3 \mathrm{~K} 14$ & \\
\hline & hMOF & $\mathrm{H} 4 \mathrm{~K} 16$ & \\
\hline & ATF2 & H2BK5, K12, K15; H4K5 & \\
\hline \multirow{17}{*}{$\begin{array}{l}\text { Histone } \\
\text { Methyltransferase } \\
\text { (HMT) }\end{array}$} & KMT1A-B & H3K9 & Repression \\
\hline & KMT1C & H3К9, Н3К27, Н3К56 & \\
\hline & KMT1D & H3К9, Н3К27 & \\
\hline & KMT1E-F & H3K9 & \\
\hline & KMT2A-G & H3K4 & Activation \\
\hline & KMT2H & H3К4, H3К36 & \\
\hline & КМТЗА & H3К36 & \\
\hline & КМТЗВ & H3K36, H4K2O & \\
\hline & КМТЗС & H3К4, Н3К36 & \\
\hline & KMT4 & H3К79 & \\
\hline & КMT5A-C & $\mathrm{H} 4 \mathrm{~K} 20$ & Repression \\
\hline & KMT6 & H3К9, H3К27 & \\
\hline & KMT7 & $\mathrm{H} 3 \mathrm{~K} 4$ & Activation \\
\hline & PRMT5 & H3R8 & Repression \\
\hline & PRMT6 & $\mathrm{H} 3 \mathrm{R} 2$ & \\
\hline & CARM1 & H3R2, R17, R26 & Activation \\
\hline & PRMT1 & H4R3 & \\
\hline \multirow{6}{*}{$\begin{array}{l}\text { Lysine } \\
\text { Demethylase } \\
\text { (KDM) }\end{array}$} & KDM1A & H3K4, H3K9 & Repression \\
\hline & KDM1B & H3K4 & \\
\hline & KDM2A & H3К36 & \\
\hline & KDM2B & H3К36, H3K4 & \\
\hline & KDMЗA-B & $\mathrm{H} 3 \mathrm{~K} 9$ & Activation \\
\hline & JMJD1C & H3K9 & \\
\hline
\end{tabular}

(Continued)
TABLE 1 | Continued

\begin{tabular}{|c|c|c|c|}
\hline Enzyme family & Examples & Catalyzed residue(s) ${ }^{*}$ & $\begin{array}{l}\text { Transcriptional } \\
\text { response }\end{array}$ \\
\hline & KDM4A & H3К9, Н3К36, H1.4K26 & $\begin{array}{l}\text { Activation/ } \\
\text { Repression }\end{array}$ \\
\hline & KDM4B & H3К9, H3К36, H1.4K26 & \\
\hline & KDM4C & H3К9, H3К36, H1.4K26 & \\
\hline & KDM4D & $\mathrm{H} 3 \mathrm{~K} 9$ & Activation \\
\hline & KDM5A-D & H3K4 & Repression \\
\hline & KDM6A & $\mathrm{H} 3 \mathrm{~K} 27$ & Activation \\
\hline & KDM6B & H3K27 & \\
\hline & KDM7A & H3K9, Н3К27 & \\
\hline & KDM8 & H3K36 & Repression \\
\hline & PHF8 & H3K9 & Activation \\
\hline & PHF2 & H3K9 & \\
\hline & NO66 & H3К4, Н3К36 & Repression \\
\hline \multirow[t]{2}{*}{ E3 ligase activity } & RING1A & H2AK119ub1 & Repression \\
\hline & RING1B & & \\
\hline
\end{tabular}

${ }^{*}$ Lysine (K), arginine (R). ${ }^{*}$ TET catalyzes $5 m C$ to 5 -hydroxymethylcytosine (5hmC), which will be repaired by thymine-DNA glycosylase (TDG) to yield non-methylated cytosine. Enzyme families reviewed in Jones (36), Di Croce and Helin (38), Seto and Yoshida (39). Keating and El-Osta (40), Kampranis and Tsichlis (41), D'Oto et al. (42), and Kohli et al. (43).

De novo methylation is mediated by DNMT3A/B whereas the reliable transmission of DNA methylation from a mother cell to a daughter cell depends on DNMT1 linked to the replication machinery (50). CpG-rich regions, termed CpG islands, are typically unmethylated but can be aberrantly methylated in cancer and during aging $(51,52)$. The relationship between CpG methylation and gene regulation is complex. Methylation in promoter regions leads to silencing, whereas methylation in the gene body may facilitate gene expression (36). Proteins containing methyl-CpG binding domains (MDB), $\mathrm{C} 2 \mathrm{H} 2$ zinc fingers, or SET-RING finger-associated (SRA) domains that recognize methylated DNA generally promote gene repression, however can also mediate gene activation $(53,54)$.

Loss of $5 \mathrm{mC}$ can occur passively through cell division (where methylation is not copied) or can be actively mediated in a replication-independent manner by Ten eleven translocation (TET) hydroxylases (48). TET hydroxylases catalyze the oxidation of $5 \mathrm{mC}$ to 5 -hydroxymethylcytosine $(5 \mathrm{hmC})$ in an $\mathrm{Fe}^{2+}$ - and $\alpha$-ketoglutarate-dependent manner (55). $5 \mathrm{hmC}$ can be iteratively oxidized by TET enzymes to other oxidized cytosines that are recognized and excised by thymine DNA glycosylase and replaced with an unmodified cytosine by base-excision repair. $5 \mathrm{hmC}$ is found in promoter gene bodies of actively transcribed genes, suggesting that it may have functions other than mediating DNA demethylation $(48,56,57)$. The importance of TET enzymes and $5 \mathrm{hmC}$ for differentiation of lymphoid and myeloid cells is well-established; however, roles for DNA methylation and $5 \mathrm{hmC}$ in regulating immune cell function have been addressed predominantly in lymphoid cells (48).

Consistent with the role of DNA methylation in regulating cellular differentiation programs, several in vitro studies have found that DNA methylation is significantly remodeled during 
DC differentiation. Cultured monocytes can differentiate to multiple lineages, depending on the cytokine cocktail provided. GM-CSF alone, or in combination with IL-4, will stimulate DC differentiation, while a GM-CSF, IL-4 and prostaglandin E2 (PGE2) cocktail will promote differentiation to monocytederived suppressor cells (MDSCs) (58-61). IL-4 signaling promotes DC differentiation by activating STAT6. STAT6 promotes the expression of DC-specific genes by recruiting TET2, which results in demethylation and increased DC-specific gene expression (62). PGE2 promotes MDSC differentiation by activating DNMT3A, which methylates and suppresses proinflammatory genes, thus supporting an immunosuppressive phenotype (63). The DNA methylome may serve to prime lineage-specific proinflammatory genes for rapid transcriptional activation upon encounter of appropriate stimuli (64). Though the DNA methylome is thought to be remarkably stable, at least one study has demonstrated that bacterial infection of human DCs leads to rapid DNA demethylation in the absence of cell division (65). In this case, loss of DNA methylation occurred most frequently at enhancers and was associated with the recruitment of dynamic TFs. Increased $5 \mathrm{hmC}$ levels were also detected, strongly implicating TET proteins in this process. Thus, surveying the genome-wide DNA methylation profile of DCs can reveal cellular adaptation patterns to extrinsic stimuli, particularly in the context of DC development and differentiation, and in the context of infection. Annotating DNA methylation to gene bodies, promoter regions or other regulatory regions may clarify the contribution of DNA methylation to gene expression programs in DCs. Furthermore, because DCs do not divide following stimulation, monitoring both $5 \mathrm{mC}$ and $5 \mathrm{hmC}$ may also shed light on dynamic changes in epigenetic control of key genes that regulate inflammatory function of DCs.

\section{Histone Modification}

The enzymatic addition or removal of chemical groups to histone tails regulates chromatin structure and therefore the location and activity of regulatory factors that control transcription. The most widely studied histone modifications are acetylation, methylation and ubiquitylation [Table 1; (38-43)]. The histone code refers to the combination of these modifications that collectively determines the outcome of gene expression (37). In general, transcriptional activation is associated with acetylation of lysine residues of histones, which promotes a more relaxed chromatin structure. Acetylation is mediated by histone acetyltransferases (HATs) and removed by histone deacetylases (HDACs). Histone methylation, on the other hand, is associated with both transcriptional activation and transcriptional repression. There are many described histone methyltransferases (HMTs) and lysine demethylases (KDM) that target a range of lysine and arginine residues (Table 1). Ubiquitination has been mostly studied in the context of the E3 ligase Really Interesting New Gene (RING) proteins that are associated with polycomb repressive complex 1 (PRC1) and deposit ubiquitin on $\mathrm{H} 2 \mathrm{~A}$.

Profiling a set of well-studied histone marks can give an overall picture of the activity of a given gene or regulatory region. $\mathrm{H} 3 \mathrm{~K} 36 \mathrm{me} 3, \mathrm{H} 3 \mathrm{~K} 27 \mathrm{Ac}$, and $\mathrm{H} 3 \mathrm{~K} 4 \mathrm{me} 3$ are commonly enriched at active genes, whereas $\mathrm{H} 3 \mathrm{~K} 27 \mathrm{me} 3$ and H3K9me3 are enriched at silenced genes. $\mathrm{H} 3 \mathrm{~K} 4 \mathrm{me} 1$ is often found at enhancers while $\mathrm{H} 3 \mathrm{~K} 4 \mathrm{me} 3$ is enriched at active promoters (66). An enhancer is considered "poised" if it carries $\mathrm{H} 3 \mathrm{~K} 4 \mathrm{me} 1$ alone or in combination with $\mathrm{H} 3 \mathrm{~K} 27 \mathrm{me} 3$, and is considered active if H3K4me1 is in combination with H3K27ac (67-70). The genome-wide histone modification profile helps determine cellular identity in part by instructing binding events at specific chromosomal loci; histone modifications can alter the accessibility of transcriptional machinery at underlying genes, or can serve as beacons to recruit chromatin remodelers to either detect, deposit, or remove these histone marks (71). Any irregularities in this system can thus threaten cellular identity, potentially initiating disease $(72,73)$. Further, several studies have argued these irregularities to be the result of an emerging player in chromatin dynamics: altered cellular metabolism (40).

\section{INTERSECTION BETWEEN IMMUNOMETABOLISM AND EPIGENETICS}

The enzymes that modify histones and DNA require specific metabolites as substrates and cofactors (Figure 1). Epigenetic modifications are therefore dependent on the availability of these metabolites and the metabolic pathways used by the cell. In turn, metabolic programming is controlled by epigenetics. Therefore, epigenetic and metabolic control of cellular function intersect at many levels.

Cellular metabolism is central to the regulation, function and activation of immune cells, including DCs. Glycolysis is a major metabolic pathway that rapidly generates energy by breaking down glucose into pyruvate in the cytosol. Pyruvate can enter the mitochondria and feed into the tricarboxylic acid (TCA) cycle, which produces reducing agents that donate electrons to the electron transport chain. This powers highly efficient energy production through a process called oxidative phosphorylation. Importantly, glycolysis and the TCA cycle generate intermediates that feed into numerous other metabolic pathways. Upon TLR stimulation, DCs shift their metabolic activity to glycolysis, and inhibiting this shift impairs DC activation $(74,75)$. The increase in glycolytic activity increases pyruvate, and subsequently citrate levels, to fuel fatty acid synthesis required to support the rapid membrane expansion that accompanies DC activation (75). Despite their similarity, cDC1s and $\mathrm{cDC} 2 \mathrm{~s}$ have recently been described to possess distinct metabolic phenotypes that are essential for their differing priming functions, with $\mathrm{cDC} 1 \mathrm{~s}$ displaying much greater oxidative metabolism (76). The epigenetic factor, polycomb group factor 6 (PCGF6), which has been found to maintain DC quiescence and limit DC activation by negatively regulating H3K4me3 levels, also impairs early glycolytic activity, as measured by extracellular acidification rate (77). Whether, PCGF6 partly limits DC activation by regulating chromatin accessibility of genes important for certain metabolic pathways is unknown.

How cellular metabolism and differing metabolic states affect the DC epigenome requires further investigation; however, several studies of conserved pathways in other innate immune cell types provide insight. Methylation requires methyl groups 


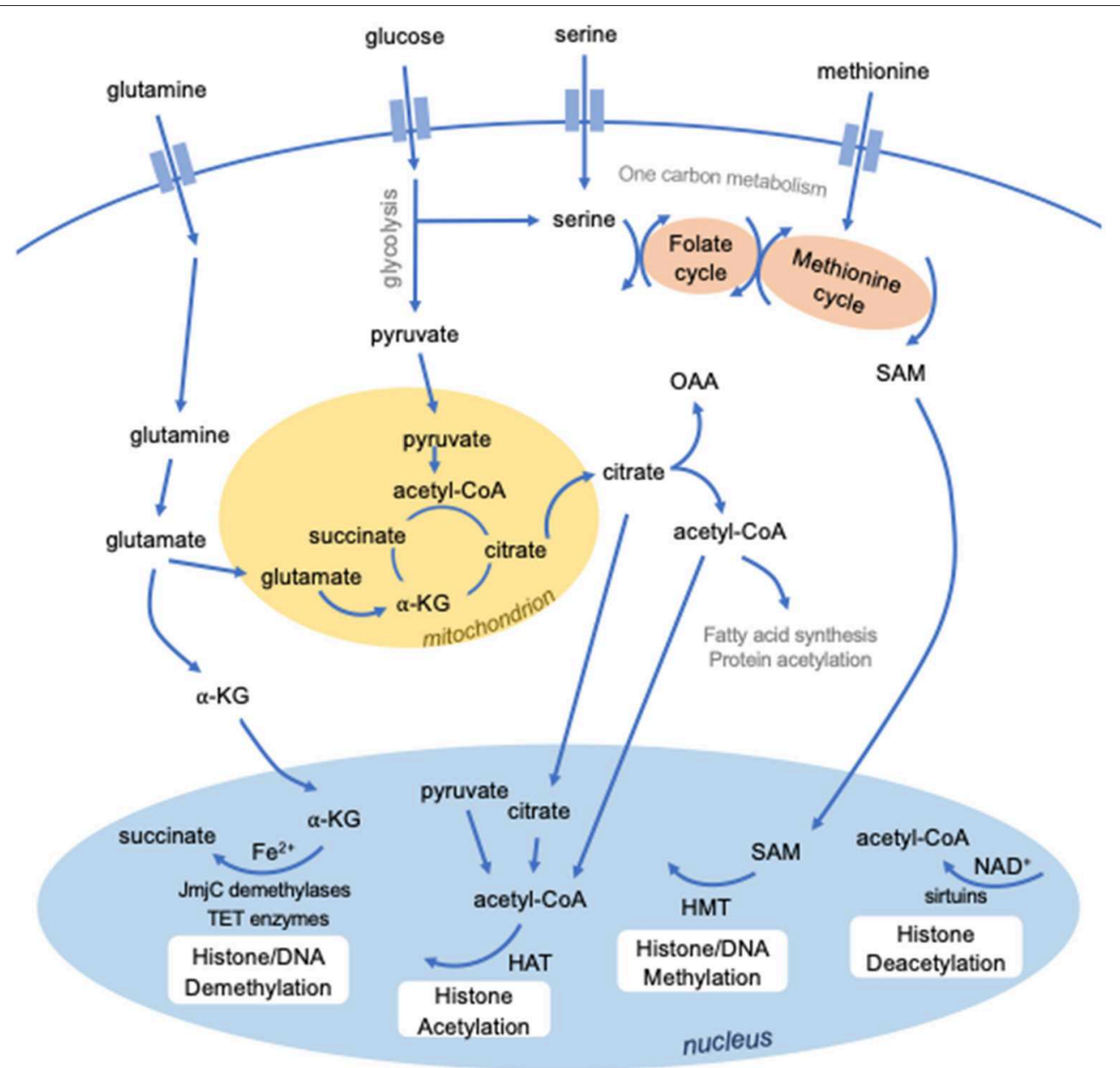

FIGURE 1 | Intersection between metabolism and epigenetics. Several metabolites are required to mediate epigenetic modifications. S-adenosylmethionine (SAM), derived from methionine and one-carbon metabolism, is used for methylation by histone methyltransferases (HMTs). Certain classes of enzymes responsible for histone (JmjC domain-containing demethylases) or DNA (TET enzymes) methylation are dependent on Fe2 ${ }^{+}$and alpha-ketoglutarate (a-KG). Histone acetylation by histone acetyltransferases requires the metabolic intermediate acetyl-CoA, which can be derived from several sources, including pyruvate, citrate, and cytosolic acetyl-CoA. Histone deacetylation by a class of histone deacetylases known as sirtuins require NAD ${ }^{+}$

provided by S-adenosyl methionine (SAM), which is generated from ATP and methionine. Limiting SAM levels can weaken the innate immune response in Caenorhabditis elegans against the bacterial pathogen Pseudomonas aeruginosa by reducing the levels of H3K4me3 at protective bacterial response genes (78). Furthermore, demethylation requires $\mathrm{Fe}^{2+}$ and $\alpha$-ketoglutarate $(\alpha-\mathrm{KG})$, as cofactor and cosubstrate, respectively, for JmjC domain-containing histone demethylases as well as TET enzymes. In macrophages, the $\alpha$-KG/succinate ratio regulates the activity of the H3K27 demethylase JMJD3, with higher $\alpha-\mathrm{KG}$ promoting JMJD3 activity at genes associated with M2 activation (79). In this instance, IL-4, which induces M2 polarization, stimulates glutaminolysis to generate $\alpha-\mathrm{KG}$ to both promote JMJD3 activity as well as to suppress the NF- $\kappa$ B pathway by activating another $\alpha$-KG-dependent enzyme, prolyl hydroxylase (79). Like succinate, several other metabolites can compete with $\alpha$-KG to inhibit $\alpha$-KG-dependent enzymes, including fumarate and 2-hydroxyglutarate $(80,81)$. Adjusting the balance of these substrates allows innate immune cells to fine-tune and modulate demethylase activity in response to external stimuli, consequently regulating their gene expression programs.

The availability of acetyl-CoA, an intermediate in several anabolic and catabolic pathways, is known to influence histone acetyltransferase activity (82). Several metabolites have also been described to activate or inhibit histone deacetylase activity (83). Importantly, a class of histone deacetylases known as sirtuins (SIRT) are dependent on the oxidizing agent $\mathrm{NAD}^{+}(84)$. During sepsis, SIRT1 and SIRT6 are responsible for a switch in metabolic phenotype from glycolysis during early acute inflammation to fatty acid oxidation in the late immunosuppressive phase (85). SIRT1 and endogenous $\mathrm{NAD}^{+}$levels increase simultaneously during endotoxin tolerance, promoting SIRT1 binding and deacetylation at the TNF $\alpha$ promoter, therefore repressing TNFA transcription (86). These findings were demonstrated in THP-1 human promonocyte cells, murine splenocytes, and whole blood leukocytes of human sepsis patients. In contrast, short-chain fatty 
TABLE 2 | Epigenetic factors that influence DC activity.

\begin{tabular}{|c|c|c|c|c|c|}
\hline & Enzyme & Function & $\begin{array}{l}\text { Known target genes in } \\
\text { DCs }\end{array}$ & Notes & References \\
\hline \multirow{5}{*}{$\begin{array}{l}\text { Promotes DC } \\
\text { activation }\end{array}$} & KDM6B (JMJD3) & H3K27 demethylase & Cd80, Cd86, CD103 & & (89) \\
\hline & WDR5 & H3K4 methyltransferase & IFNA, IFNB & & (90) \\
\hline & KDM4D (JMJD2D) & H3K9 demethylase & $1 / 12, \| 23$ & Recruited by Trabid & (91) \\
\hline & $\begin{array}{l}\text { NuRD complex (HDAC1, } \\
\text { HDAC2) }\end{array}$ & $\begin{array}{l}\text { Histone deacetylation } \\
\text { complex }\end{array}$ & $\begin{array}{l}\text { Tnfrsf9, Cd40, Cd80, } \\
\text { Cd86, Cd68, Slc11a, } \\
\text { Ciita. H2-Aa }\end{array}$ & Recruited by Mbd2 & $(92)$ \\
\hline & HDAC11 & Histone deacetylase & IL10 & & (93) \\
\hline \multirow{4}{*}{$\begin{array}{l}\text { Promotes DC } \\
\text { steady-state }\end{array}$} & PCGF6 & Transcriptional repressor & Ciita, $H 2-A b 1,\|/ 12 a\| 12 b$, & Forms complex with KDM5C & $(77)$ \\
\hline & KDM5B & H3K4 demethylase & Ifnb, II6, Tnfa & Upregulated by RSV & (94) \\
\hline & HDAC2 & Histone deacetylase & 116 & Recruited by Tet2 & (95) \\
\hline & G9a & H3K9 methyltransferase & Ifna, Ifnb & & (96) \\
\hline
\end{tabular}

acids produced by the gut microbiota inhibit histone deacetylase activity (87). The most potent of these short-chain fatty acids is butyrate, which contributes to immune tolerance to commensal bacteria by inhibiting proinflammatory functions of intestinal macrophages (88). Clearly, the functions of innate immune cells are regulated by the exquisite interconnection between epigenetic and metabolic reprogramming. Further studies are required to identify the importance of metabolic-epigenetic interactions for DC function.

\section{EPIGENETIC REGULATION OF DC FUNCTIONS}

Expanding evidence suggests that epigenetic modifications contribute significantly to the regulation of DC function. Epigenetic mechanisms are implicated in the maintenance of the steady-state, responses to activating stimuli, trained immunity, and tolerance (Table 2). Furthermore, metabolism, nutrition, environment, and aging also impact DC function by influencing the epigenetic landscape. Ultimately, these mechanisms are important to understand as they impact immune responses to infections and cancers and contribute to inflammatory diseases such as autoimmunity and asthma.

\section{Active Maintenance of DC Homeostasis}

Maintaining DC homeostasis requires balancing of the mechanisms that repress activation and those that promote proinflammatory functions. Clues from the study of TFs suggest that active restraint of DC activation is regulated at the level of transcription. NF- $\kappa \mathrm{B}$, which is recognized to have pioneer factor activity, has been widely shown to induce inflammatory gene expression programs in part by promoting chromatin remodeling $(97,98)$. At steady state, NF- $\kappa$ B restrains DC activation and prevents DCs from inducing self-reactive cytotoxic T cell responses (99). Deficiency of the p50 subunit of $\mathrm{NF}-\kappa \mathrm{B}$ in DCs leads to the spontaneous induction of diabetes in a mouse model (99). However, NF- $\kappa \mathrm{B}$ activity is also well-known to drive DC activation. One study, using genome footprinting and chromatin immunoprecipitation (ChIP), revealed that the promoter of the MHC class II transactivator CIITA is occupied by
NF- $\kappa \mathrm{B}$ (p65) at steady-state but not in activated DCs, suggesting that NF- $\kappa$ B relocates when DCs become activated (100). Whether the chromatin landscape dictates NF- $\kappa \mathrm{B}$ binding in steady-state vs. activated state remains to be determined.

Interestingly, lineage-specific factors that contribute to the differentiation of DCs have also been described to be downregulated in response to maturation signals (101-103). For example, expression of ZBTB46, a zinc-finger DNA-binding TF, is restricted to cDCs. Downregulation of ZBTB46 accompanies TLR-stimulation and is necessary to permit activation $(101,104)$. Once committed, the lineage of DCs is highly stable $(4,28)$, therefore it is possible that sustained expression of lineagespecifying factors may serve to restrain the full maturation of DCs until the appropriate activating signals are received.

PCGF6 is a member of Polycomb Repressive Complex 1 (PRC1.6). PRC1 complexes are well-known for catalyzing the monoubiquitylation of histone $\mathrm{H} 2 \mathrm{~A}$ by a RING E3 ligase $(105,106)$. H2AK119ub1 leads to chromatin compaction and gene silencing. PCGF6 participates in non-canonical complexes including ones containing E2F6, which promote gene silencing by promoting $\mathrm{H} 3 \mathrm{~K} 9$ trimethylation, and others that contain KDM5C/D lysine demethylases that remove activating methyl marks at H3K4 (77, 107-112). PCGF6 and KDM5C were both found to be necessary for maintenance of the steady state (77). Following PRR stimulation, PCGF6 is rapidly downregulated, enabling DC activation. PCGF6 regulates the chromatin landscape in DCs and more specifically the levels of H3K4me3 at genes important for DC activation. Though few, these studies suggest that optimal maintenance of the steady state of DCs requires active repression of inflammation-sensitive gene loci through epigenetic silencing at steady state (Figure 2). Rapid relief of transcriptional and epigenetic restraints in response to stimulation is required for massive transcriptional reprogramming that supports DC activation and function.

\section{Epigenetic Mechanisms Underpin DC Activation and Function}

The chromatin landscape at steady state likely dictates the early responses to activating stimuli by regulating accessibility of genes important for DC activation. Following the transcriptional 

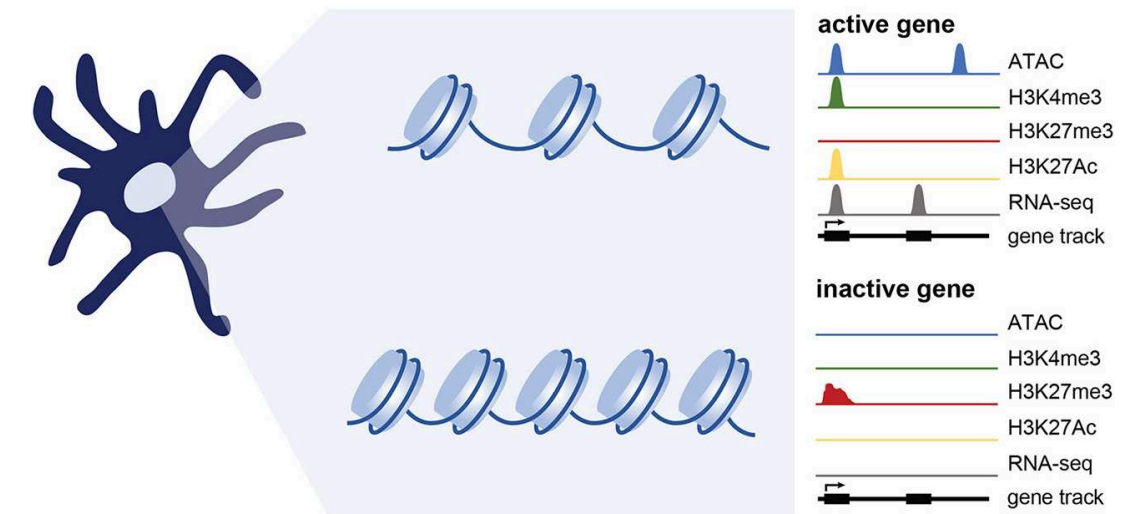

FIGURE 2 | Epigenetic changes associated with gene expression. Simplified representation of data profiles of ATAC-seq, ChIP-seq, and RNA-seq showing an active or inactive gene. Active genes are accessible (measured using ATAC-seq) and bear chromatin modifications associated with transcriptional activation such as H3K4me3 and H3K27Ac. Genes that are inactive are maintained in a repressed, less accessible state and are marked by histone modifications such as H3K27me3. While not extensively tested in DCs, genes poised for expression likely maintain accessibility, and may have a mix of activating and repressive marks.

reprogramming that accompanies DC activation, epigenetic reinforcement of gene expression becomes essential to ensure that DCs migrating to lymph nodes retain gene expression profiles to appropriately initiate $\mathrm{T}$ cell responses. To activate $\mathrm{T}$ cells, DCs must provide at least three signals: antigen presentation (signal 1), co-stimulation (signal 2), and lineage-specifying cytokine production (signal 3). The expression of proteins that constitute these signals are regulated transcriptionally, and increasing evidence suggests they are also regulated epigenetically. In steady-state splenic DCs, the expression of costimulatory molecules $C d 80$ and $C d 86$ is repressed by $\mathrm{H} 3 \mathrm{~K} 27 \mathrm{me}$, which is relieved by the $\mathrm{H} 3 \mathrm{~K} 27$ demethylase KDM6B (JMJD3) during LPS stimulation (89). Furthermore, the repressive mark $\mathrm{H} 3 \mathrm{~K} 9 \mathrm{me} 3$ was found to be enriched at the promoters of proinflammatory cytokines $l l 12 a$, $I l 12 b$, and Il23 in steady-state BMDCs. Upregulation of these cytokines in LPS-activated BMDCs is largely governed by the recruitment of Trabid, a deubiquitinase that stabilizes the H3K9 demethylase KDM4D (JMJD2D) (91). Nucleosome Remodeling Deacetylase complex (NuRD) also reinforces DC activation by suppressing antigen uptake and processing $(C d 68, S l c 11 a)$ and stimulating antigen presentation (Ciita, $\mathrm{H} 2-\mathrm{Aa}$ ) (92). This occurs by stabilizing antigen-loaded MHC and by upregulation of specific costimulatory molecules and cytokines. Though these studies suggest that a dynamic epigenome is important for proper DC function, a comprehensive study focused on early and late-stage changes in the chromatin landscape following stimulation and the importance for DC function has not been reported.

Immune mediators in the inflammatory microenvironment such as cytokines, chemokines, and lipids, can temper DC responses to activating stimuli. IL-10 has long been known to potently downregulate IL-12 production (113). HDAC11 represses IL10 and in doing so, promotes the activation and IL-12 production of primary human DCs, which is required for efficient $\mathrm{CD}^{+} \mathrm{T}$ cell differentiation (93). STAT6, a downstream effector of IL-4 signaling, also antagonizes histone acetylation at the Il10 promoter following LPS stimulation (114). Lipid mediators, such as prostaglandins, can also be sculptors of the epigenome in DCs. Prostaglandin I2 suppresses H3K4me3 enrichment at the TNFA promoter by inhibiting components of a methyltransferase complex, MLL and WDR5, from translocating into the nucleus (115). A further study by the same group found that antagonism of the cysteinyl leukotriene receptor promotes an anti-inflammatory phenotype in human moDCs by enhancing $\mathrm{H} 3$ acetylation at the IL10 promoter (116). Inhibiting chromatin remodelers could be an effective therapeutic avenue for inflammatory conditions, in particular those driven by TNF $\alpha$ or controlled by IL-10. Together these studies demonstrate that epigenetic mechanisms significantly contribute to the activation of DCs, and importantly, that factors in the inflammatory environment that modify the epigenome may have lasting effects on DC responsiveness.

\section{Trained Immunity and Tolerance}

The response of myeloid cells can be influenced by previous exposure to inflammatory stimuli. Exposure of DCs and macrophages to low levels of endotoxin induces tolerance which decreases their sensitivity to subsequent stimuli. Exposure of cells to stimuli that increases subsequent responsiveness is termed "trained immunity" and is most commonly noted in monocytes; whether trained immunity is transferred to monocyte-derived DCs upon differentiation is not known. There is increasing evidence that epigenetic and metabolic programming underlies tolerance and training of myeloid cells $(98,117)$.

Tolerance in myeloid cells, including DCs, is a refractory period following proinflammatory stimulation whereby the immune system is non-responsive to subsequent threats. During sepsis, for example, tolerance serves as a protective mechanism to prevent endotoxin shock in the host. In this state, monocytes, DCs, and macrophages adopt a chromatin landscape that predominantly favors immune suppression $(29,31)$. This is in part accomplished by the upregulation of suppressive factors such as IL-10, PD-L1, IDO, and TGF $\beta$, along with concomitant 
silencing of IL-12 and other proinflammatory mediators. These changes in gene expression are accompanied by changes in H3K27me3, H3K27Ac, and H3K4me3 enrichment (29, 31, 118). HDAC2 activity at the Il6 promoter during late-stage inflammation can lead to Il6 downregulation and a subsequent return to homeostasis (95).

Training of monocytes by $\beta$-glucan stimulation leads to epigenetic and metabolic alterations that prime proinflammatory genes for enhanced expression in response to further stimulation (117). Bacillus Calmette-Guérin (BCG) exposure also trains monocytes to enhance their responses against Mycobacterium tuberculosis infection $(119,120)$. Training can occur at the level of hematopoietic stem cells, leading to unique epigenetic and metabolic signatures in macrophages arising from BCGtrained monocytes (120). BCG and $\beta$-glucan training is dependent on glycolysis induced through key metabolic regulators mTOR and $\operatorname{HIF}-1 \alpha(119,121)$. Innate immune memory may also occur in microglia, myeloid cells in the brain, affecting neuropathology in murine models of stroke and Alzheimer's. HIF- $1 \alpha$ levels are similarly increased in the trained microglia suggesting metabolic reprogramming may underlie training (122). A transcriptomics and metabolomics approach uncovered that glycolysis, glutaminolysis and cholesterol synthesis are essential metabolic pathways for inducing the trained phenotype in monocytes (123). Fumarate accumulation resulting from increased glutaminolysis leads to inhibition of histone demethylases and an increase in H3K4me3 marks at the promoters of proinflammatory cytokines. In addition, mevalonate, a metabolite from the cholesterol synthesis pathway, induces trained immunity by autocrine signaling through IGF1 receptor and subsequent mTOR activation (124). Collectively, these studies suggest that cells of the myeloid lineage undergo epigenetic and metabolic reprogramming in response to environmental stimuli that alters subsequent responses to stimuli. The extent to which environmental stimuli alters metabolic and epigenetic programming of DCs and alters their subsequent responses remains to be studied in detail.

\section{Viral Infection}

The study of antiviral immunity has provided key insights into the contribution of epigenetic mechanisms to DC activation. For instance, interferon production by human DCs can be activated or suppressed by functionally dichotomous chromatin remodelers; the H3K4-specific methyltransferase WDR5 stimulates antiviral immunity via $\mathrm{H} 3 \mathrm{~K} 4$ trimethylation at the IFNA and IFNB promoters (90), while H3K9me2 enrichment by the histone-lysine $\mathrm{N}$-methyltransferase G9a at IFNA and IFNB promoters instead correlates with a decreased DCdriven antiviral response (96). Although a practical system to ensure appropriate interferon expression, certain pathogens have evolved strategies to hijack these endogenous epigenetic pathways and skew the epigenetic signature in their favor. Respiratory syncytial virus (RSV) infection can be cleared by a $\mathrm{T}_{\mathrm{H}} 1$ cytokine profile, but RSV-infected patients often mount a $\mathrm{T}_{\mathrm{H}} 2$ cytokine response non-conducive to efficient RSV clearance. One group found aberrant $\mathrm{T}_{\mathrm{H}} 2$ responses to be driven by an RSV-mediated upregulation of endogenous H3K4
TABLE 3 | Environmental factors that shape the epigenome in DCs.

\begin{tabular}{llc}
\hline Extrinsic agent & Effect on DC function & References \\
\hline Aging & $\begin{array}{l}\text { Increase in global DNA hypomethylation } \\
\text { Upregulation of TNFA, IL 1A, IL17RC, } \\
\text { TLR2, II23p19 }\end{array}$ & $(126)$ \\
Chemicals & & $(127-132)$ \\
Phthalates & Enhance TH2 allergic responses \\
Nutrition & Downregulate IRF7 \\
Zinc deficiency & $\begin{array}{l}\text { Induces I/6 promoter demethylation } \\
\text { Vitamin C }\end{array}$ & $\begin{array}{l}\text { Increases NF-kB activation, IL-12p70 } \\
\text { secretion } \\
\text { Regulates TET-mediated DNA } \\
\text { demethylation (ES cells, lymphomas) }\end{array}$ \\
Lipid Mediator & $\begin{array}{l}\text { Reduces H3K4me3 enrichment at } \\
\text { Prostaglandin I2 }\end{array}$ & $\begin{array}{l}\text { TNFA promoter } \\
\text { Reduces H3 acetylation at IL10 } \\
\text { promoter }\end{array}$ \\
Cysteinyl & leukotrienes &
\end{tabular}

demethylase KDM5B in several DC types, a transcriptional repressor of $\mathrm{T}_{\mathrm{H}} 1$-associated cytokines important for RSV clearance (94). Furthermore, during viral infection in mice, TET2 is recruited by CXXC5 to the Irf7 promoter to induce Irf7 hypomethylation and expression in pDCs, resulting in the onset of an antiviral response (125). Given the role of TET2 in stabilizing HDAC2 at the Il6 promoter (as described earlier), TET2 drives dichotomous DC functions; while TET2 can recruit HDAC2 to help repress Il6 and resolve IL-6driven inflammation, it can also initiate an inflammatory antiviral response by hypomethylating and upregulating Irf7 expression. Advances in both the understanding of the biochemical function of $5 \mathrm{hmC}$ and TET enzymes in DCs are necessary to fully appreciate the role of dynamic changes in DNA methylation for regulating gene expression during infection.

\section{ENVIRONMENTAL FACTORS}

A hallmark of the epigenome is its proclivity to undergo extensive remodeling in response to environmental stimuli. Though understudied, accumulating evidence demonstrates that extrinsic factors (in addition to microbes and inflammatory mediators), such as nutrients, chemicals and even aging, can manipulate DC function by altering the epigenetic landscape [Table 3; (139)].

\section{Chemicals and Nutrients}

Phthalates, endocrine-disrupting chemicals ubiquitous in the plastic industry, have been shown to possess adjuvant-like properties that enhance $\mathrm{T}_{\mathrm{H}} 2$ allergic responses (133). Phthalates were found to downregulate IRF7 expression in human pDCs by inhibiting H3K4-specific methyltransferase WDR5 translocation into the nucleus (134). Nutrients from the diet are also 
known to affect immune cell function through epigenetic regulation. For example, recent estimates suggest a notable zinc deficiency in $65 \%$ of the senior population ( $>65$ years old) (140). Zinc deficiency can inappropriately enhance inflammatory responses (141); zinc deficiency was found to correlate with Il6 promoter demethylation in THP-1 cells, which led to increased IL-6 production and inflammation (135). Several studies have also established vitamin $\mathrm{C}$ as a modulator of DNA demethylation $(137,138)$. Vitamin C can directly regulate TET-mediated DNA demethylase activity in lymphoma and ES cells. Since vitamin C treatment has been shown to increase NF- $\kappa$ B activation and enhance IL-12p70 secretion by BMDCs (136), vitamin C may promote inflammation by demethylation of genes important for DC activation. As we continue to better understand the mechanisms by which nutrition and metabolism regulate cellular physiology, more links are likely to become apparent between these small molecules and epigenetics.

\section{Aging}

Immune aging or "inflammaging" refers to the observed increase in proinflammatory cytokine expression, such as $\mathrm{TNF} \alpha$, by aged innate cells in the absence of acute infection or stimulation (142). Transcriptional dysregulation in many cell types, including non-immune cells, has been shown to correlate with stochastic epigenetic modifications incurred with age, a process known as "epigenetic drift" (143). An early study found a positive correlation between age and global DNA hypomethylation (126), with several later studies reporting demethylation and concomitant dysregulation at key proinflammatory genes, including TNFA (127, 128), IL1A (129), IL17RC (130), and TLR2 (131). Splenic T cells from aged C57BL/6 mice (>22 months old) show elevated levels of IL-17 secretion (144). Accordingly, increased IL-17 production is also observed in many autoimmune diseases (145), therefore epigenetic drift in DCs may underlie increased age-related incidences in autoimmunity. Indeed, the activation marker $\mathrm{H} 3 \mathrm{~K} 4 \mathrm{me} 2$ is enriched at the Il23p19 promoter in aged DCs (132), and IL-23 production is known to play a pivotal role in the maintenance and expansion of $\mathrm{T}_{\mathrm{H}} 17$ immune responses (146). Inflammation ultimately has the capacity to influence epigenetic regulation (147) and therefore may impact age-associated epigenetic changes in immune and non-immune cells. The interconnectivity of these processes likely underlies long-term immune functionality and organismal health.

\section{INFLAMMATORY DISEASES}

DCs are an important driver of the inflammation associated with autoimmune disease and allergic asthma. In particular, histone demethylases and hydroxylases containing the JmjC domain, including $\mathrm{KDM} 5 \mathrm{C}$, JMJD2D, and JMJD3, appear to play a significant role in DC-mediated pathogenesis. KDM5C is an important regulator of the steady-state and activation of murine DCs (77). TRABID promotes experimental autoimmune encephalitis (EAE) by stabilizing JMJD2D at the Il12 promoter, enhancing IL-12 production and immunopathology (91). However, JMJD3 inhibition limits EAE pathology and promotes a tolerogenic DC profile characterized by the reduced expression of $\mathrm{CD} 80 / 86$, and reduced secretion of proinflammatory cytokines IL-6, IFN- $\gamma$, and TNF $\alpha$ (89). Several diseases have been linked to aberrant DC methylation profiles in DCs. DNA hypermethylation at the IRF8 promoter has been noted in Ocular Behcet's Disease (148) and KoyanagiHarada Disease (149). In both cases, pharmacological DNA demethylation suppressed proinflammatory cytokine production by patient-derived DCs ex vivo. In contrast, genome-wide DNA demethylation was observed in the pDCs of patients with systemic lupus erythematosus (SLE), resulting in increased IFNA expression which could contribute to SLE onset (150).

Epigenetic modifications have also been described in asthma (151). Upon allergen recognition in the lung, lung-resident DCs upregulate chemokine receptor CCR7, allowing for their migration to the mediastinal lymph nodes, where they prime $\mathrm{T}$ cells and promote allergic inflammation. Although several lung-resident DC subsets exist (including cDCs and moDCs), Ccr7 upregulation is relatively cDC-specific (152). H3K27me3 enrichment was found at the Ccr7 promoter in moDCs, but not cDCs, suggesting that some lineage specific functions of DCs may be epigenetically determined (153). Mouse studies also suggest asthma risk to be an inherited characteristic partially mediated by an altered DC epigenome. Adoptive transfer experiments in mice identified DCs to be the "carrier" of asthmatic susceptibility; DCs transferred from neonates of asthmatic mothers to neonates of non-asthmatic mothers increased asthma susceptibility in the recipients, indicating a functional skew in DCs early in life that promote allergic responses (154). Donor and recipient mice were genetically identical, suggesting the observed functional skew to be epigenetically regulated. Indeed, the DC methylomes of neonates from asthmatic mothers differed significantly from neonates of healthy mothers, and approximately $50 \%$ of the differentially methylated genes belong to allergy and asthma pathology networks (155). Thus, allergen exposure early in life results in alternative epigenetic regulation of key genes that contribute to allergic responses. Thus, the extent to which inflammatory genes are epigenetically primed in DCs likely contributes to inflammatory disease incidence and severity.

\section{SUMMARY AND PERSPECTIVES}

Because DCs are fast-acting and short-lived, the contribution of epigenetic mechanisms to DC responsiveness and function has been overlooked. However, there is growing appreciation of the importance of epigenetic mechanisms in controlling dynamic, and even short-lived, cellular responses. The past decade has seen exciting advancements in our understanding of how the environment impacts immunobiology at the epigenome level. Significant steps have been taken to understand how the chemicals and nutrients in our environment influence the immune system, as well as the mechanisms by which the aging process contributes to age-related inflammation. 
The development and use of low-input techniques are necessary to expand epigenetic studies to different in vivo-derived DC populations $(46,156,157)$. Further studies are needed to expand our knowledge of the mechanisms that regulate the epigenome in DCs and the consequences for healthy and pathological inflammation. DC function is highly influenced by the local environment in which it is stimulated. Thus, environmental factors that shape the epigenome of DCs at steady state are likely to have lasting effects on DC function. Insightful discoveries on the effects of local nutrition, metabolite availability, and inflammation on the epigenetic landscape in DCs will further our understanding of the dynamic changes in gene expression that support or interfere with host immunity.

\section{REFERENCES}

1. Liu K, Victora GD, Schwickert TA, Guermonprez P, Meredith MM, Yao K, et al. In vivo analysis of dendritic cell development and homeostasis. Science. (2009) 324:392-7. doi: 10.1126/science.1170540

2. Naik SH, Sathe P, Park H-Y, Metcalf D, Proietto AI, Dakic A, et al. Development of plasmacytoid and conventional dendritic cell subtypes from single precursor cells derived in vitro and in vivo. Nat Immunol. (2007) 8:1217-26. doi: 10.1038/ni1522

3. Onai N, Obata-Onai A, Schmid MA, Ohteki T, Jarrossay D, Manz MG. Identification of clonogenic common Flt3+M-CSFR+ plasmacytoid and conventional dendritic cell progenitors in mouse bone marrow. Nat Immunol. (2007) 8:1207-16. doi: 10.1038/ni1518

4. Schlitzer A, Sivakamasundari V, Chen J, Sumatoh HRB, Schreuder $\mathrm{J}$, Lum J, et al. Identification of $\mathrm{cDC} 1$ - and $\mathrm{CDC} 2$-committed $\mathrm{DC}$ progenitors reveals early lineage priming at the common DC progenitor stage in the bone marrow. Nat Immunol. (2015) 16:718-28. doi: 10.10 38/ni.3200

5. Fogg DK, Sibon C, Miled C, Jung S, Aucouturier P, Littman DR, et al. A clonogenic bone marrow progenitor specific for macrophages and dendritic cells. Science. (2006) 311:83-7. doi: 10.1126/science.1117729

6. Price JD, Tarbell KV. The role of dendritic cell subsets and innate immunity in the pathogenesis of type 1 diabetes and other autoimmune diseases. Front Immunol. (2015) 6:288. doi: 10.3389/fimmu.2015.00288

7. Merad M, Sathe P, Helft J, Miller J, Mortha A. The dendritic cell lineage: ontogeny and function of dendritic cells and their subsets in the steady state and the inflamed setting. Annu Rev Immunol. (2013) 31:563604. doi: 10.1146/annurev-immunol-020711-074950

8. Schlitzer A, McGovern N, Ginhoux F. Dendritic cells and monocyte-derived cells: two complementary and integrated functional systems. Semin Cell Dev Biol. (2015) 41:9-22. doi: 10.1016/j.semcdb.2015.03.011

9. Schlitzer A, Zhang W, Song M, Ma X. Recent advances in understanding dendritic cell development, classification, and phenotype. F1000Res. (2018) 7:1-9. doi: 10.12688/f1000research.14793.1

10. Durai V, Murphy KM. Functions of murine dendritic cells. Immunity. (2016) 45:719-36. doi: 10.1016/j.immuni.2016.10.010

11. Garber M, Yosef N, Goren A, Raychowdhury R, Thielke A, Guttman M, et al. A high-throughput chromatin immunoprecipitation approach reveals principles of dynamic gene regulation in mammals. Mol Cell. (2012) 47:81022. doi: 10.1016/j.molcel.2012.07.030

12. Lin Q, Chauvistré H, Costa IG, Gusmao EG, Mitzka S, Hänzelmann S, et al. Epigenetic program and transcription factor circuitry of dendritic cell development. Nucleic Acids Res. (2015) 43:9680-93. doi: 10.1093/nar/gkv1056

13. Guerriero A, Langmuir PB, Spain LM, Scott EW. PU.1 is required for myeloid-derived but not lymphoid-derived dendritic cells. Blood. (2000) 95:879-85.

\section{AUTHOR CONTRIBUTIONS}

GB, MC, HG, and CK contributed by researching and writing manuscript and creating figures and tables.

\section{FUNDING}

This work was supported by CHIR grants MOP-126184 and SVB-158625 and the Cancer Research Society G246862.

\section{ACKNOWLEDGMENTS}

We would like to thank Kelsey Williams, Hui Shen, and Russell Jones for discussion, comments, and advice.

14. Laiosa CV, Stadtfeld M, Xie H, de Andres-Aguayo L, Graf T. Reprogramming of committed $\mathrm{T}$ cell progenitors to macrophages and dendritic cells by C/EBP alpha and PU.1 transcription factors. Immunity. (2006) 25:73144. doi: 10.1016/j.immuni.2006.09.011

15. Belz GT, Nutt SL. Transcriptional programming of the dendritic cell network. Nat Rev Immunol. (2012) 12:101-13. doi: 10.1038/nri3149

16. Anderson DA III, Murphy KM, Briseño CG. Development, diversity, and function of dendritic cells in mouse and human. Cold Spring Harb Perspect Biol. (2018) 10: a028613. doi: 10.1101/cshperspect.a028613

17. Shortman K, Naik SH. Steady-state and inflammatory dendritic-cell development. Nat Rev Immunol. (2007) 7:19-30. doi: 10.1038/nri1996

18. Sallusto F, Lanzavecchia A. Efficient presentation of soluble antigen by cultured human dendritic cells is maintained by granulocyte/macrophage colony-stimulating factor plus interleukin 4 and downregulated by tumor necrosis factor alpha. J Exp Med. (1994) 179:1109-18.

19. Inaba $K$, Inaba $M$, Romani $N$, Aya $H$, Deguchi $M$, Ikehara S, et al. Generation of large numbers of dendritic cells from mouse bone marrow cultures supplemented with granulocyte/macrophage colony-stimulating factor. $J$ Exp Med. (1992) 176:1693-702. doi: 10.1084/jem.176.6.1693

20. Mellman I, Steinman RM. Dendritic cells: specialized and regulated antigen processing machines. Cell. (2001) 106:255-258. doi: 10.1016/S0092-8674(01)00449-4

21. Helft J, Böttcher J, Chakravarty P, Zelenay S, Huotari J, Schraml BU, et al. GM-CSF mouse bone marrow cultures comprise a heterogeneous population of CD11c+ MHCII+ macrophages and dendritic cells. Immunity. (2015) 42:1197-211. doi: 10.1016/j.immuni.2015.05.018

22. Vander Lugt B, Riddell J, Khan AA, Hackney JA, Lesch J, DeVoss J, et al. Transcriptional determinants of tolerogenic and immunogenic states during dendritic cell maturation. J Cell Biol. (2017) 216:77992. doi: $10.1083 /$ jcb. 201512012

23. Naik SH, Proietto AI, Wilson NS, Dakic A, Schnorrer P, Fuchsberger M, et al. Cutting edge: generation of splenic CD8+ and CD8- dendritic cell equivalents in Fms-Like tyrosine kinase 3 ligand bone marrow cultures. $J$ Immunol. (2005) 174:6592-7. doi: 10.4049/jimmunol.174.11.6592

24. Brawand P, Fitzpatrick DR, Greenfield BW, Brasel K, Maliszewski CR, De Smedt T. Murine plasmacytoid pre-dendritic cells generated from Flt3 ligand-supplemented bone marrow cultures are immature APCs. J Immunol. (2002) 169:6711-9. doi: 10.4049/jimmunol.169.12.6711

25. Gilliet M, Boonstra A, Paturel C, Antonenko S, Xu X-L, Trinchieri G, et al. The development of murine plasmacytoid dendritic cell precursors is differentially regulated by FLT3-ligand and granulocyte/macrophage colonystimulating factor. J Exp Med. (2002) 195:953-8. doi: 10.1084/jem.20020045

26. Brasel K, De Smedt T, Smith JL, Maliszewski CR. Generation of murine dendritic cells from flt3-ligand-supplemented bone marrow cultures. Blood. (2000) 96:3029-39.

27. Kirkling ME, Cytlak U, Lau CM, Lewis KL, Resteu A, KhodadadiJamayran A, et al. Notch signaling facilitates in vitro generation of 
cross-presenting classical dendritic cells. Cell Rep. (2018) 23:365872.e6. doi: 10.1016/j.celrep.2018.05.068

28. Bornstein C, Winter D, Barnett-Itzhaki Z, David E, Kadri S, Garber $\mathrm{M}$, et al. A negative feedback loop of transcription factors specifies alternative dendritic cell chromatin States. Mol Cell. (2014) 56:74962. doi: 10.1016/j.molcel.2014.10.014

29. Foster SL, Hargreaves DC, Medzhitov R. Gene-specific control of inflammation by TLR-induced chromatin modifications. Nature. (2007) 447:972-8. doi: 10.1038/nature05836

30. De Santa F, Narang V, Yap ZH, Tusi BK, Burgold T, Austenaa L, et al. Jmjd3 contributes to the control of gene expression in LPS-activated macrophages. EMBO J. (2009) 28:3341-52. doi: 10.1038/emboj.2009.271

31. Huang Y, Min S, Lui Y, Sun J, Su X, Liu Y, et al. Global mapping of H3K4me3 and H3K27me3 reveals chromatin state-based regulation of human monocyte-derived dendritic cells in different environments. Genes Immun. (2012) 13:311-20. doi: 10.1038/gene.2011.87

32. Mullen AC, Orlando DA, Newman JJ, Lovén J, Kumar RM, Bilodeau S, et al. Master transcription factors determine cell-type-specific responses to TGF- $\beta$ signaling. Cell. (2011) 147:565-76. doi: 10.1016/j.cell.2011.08.050

33. Platanitis E, Decker T. Regulatory Networks Involving STATs, IRFs, and NFKB in Inflammation. Front Immunol. (2018) 9:2542. doi: $10.3389 /$ fimmu.2018.02542

34. Ivashkiv LB, Donlin LT. Regulation of type I interferon responses. Nat Rev Immunol. (2014) 14:36-49. doi: 10.1038/nri3581

35. Wei J-W, Huang K, Yang C, Kang C-S. Non-coding RNAs as regulators in epigenetics. Oncology Reports. (2017) 37:3-9. doi: 10.3892/or.2016.5236

36. Jones PA. Functions of DNA methylation: islands, start sites, gene bodies and beyond. Nat Rev Genet. (2012) 13:484-92. doi: 10.1038/nrg3230

37. Rothbart SB, Strahl BD. Interpreting the language of histone and DNA modifications. Biochim Biophys Acta. (2014) 1839:62743. doi: 10.1016/j.bbagrm.2014.03.001

38. Di Croce L, Helin K. Transcriptional regulation by Polycomb group proteins. Nat Struct Mol Biol. (2013) 20:1147-55. doi: 10.1038/nsmb.2669

39. Seto E, Yoshida M. Erasers of histone acetylation: the histone deacetylase enzymes. Cold Spring Harb Perspect Biol. (2014) 6:a018713. doi: 10.1101/cshperspect.a018713

40. Keating ST, El-Osta A. Epigenetics and metabolism. Circ Res. (2015) 116:715-36. doi: 10.1161/CIRCRESAHA.116.303936

41. Kampranis SC, Tsichlis PN. Histone demethylases and cancer. Adv Cancer Res. (2009) 102:103-169. doi: 10.1016/S0065-230X(09)02004-1

42. D'Oto A, Tian Q-W, Davidoff AM, Yang J. Histone demethylases and their roles in cancer epigenetics. J Med Oncol Ther. (2016) 1:34-40.

43. Kohli RM, Zhang Y. TET enzymes, TDG and the dynamics of DNA demethylation. Nature. (2013) 502:472-9. doi: 10.1038/nature12750

44. Apostolou E, Hochedlinger K. Chromatin dynamics during cellular reprogramming. Nature. (2013) 502:462-71. doi: 10.1038/ nature 12749

45. Zhao Y, Garcia BA. Comprehensive Catalog of Currently Documented Histone Modifications. Cold Spring Harb Perspect Biol. (2015) 7:a025064. doi: 10.1101/cshperspect.a025064

46. Buenrostro JD, Giresi PG, Zaba LC, Chang HY, Greenleaf WJ. Transposition of native chromatin for fast and sensitive epigenomic profiling of open chromatin, DNA-binding proteins and nucleosome position. Nat Methods. (2013) 10:1213-8. doi: 10.1038/nmeth.2688

47. Yoshida H, Lareau CA, Ramirez RN, Rose SA, Maier B, Wroblewska A, et al. The cis-Regulatory Atlas of the Mouse Immune System. Cell. (2019) 176:897-912.e20. doi: 10.1016/j.cell.2018.12.036

48. Lio C-WJ, Rao A. TET Enzymes and $5 \mathrm{hmC}$ in Adaptive and Innate Immune Systems. Front Immunol. (2019) 10:210. doi: 10.3389/fimmu.2019.00210

49. Shen H, Laird PW. Interplay between the cancer genome and epigenome. Cell. (2013) 153:38-55. doi: 10.1016/j.cell.2013.03.008

50. Probst AV, Dunleavy E, Almouzni G. Epigenetic inheritance during the cell cycle. Nat Rev Mol Cell Biol. (2009) 10:192-206. doi: 10.1038/nrm2640

51. Horvath S. DNA methylation age of human tissues and cell types. Genome Biol. (2013) 14:R115. doi: 10.1186/gb-2013-14-10-r115

52. Toyota M, Issa JP. CpG island methylator phenotypes in aging and cancer. Semin Cancer Biol. (1999) 9:349-57. doi: 10.1006/scbi.1999.0135
53. Hudson NO, Buck-Koehntop BA. Zinc finger readers of methylated DNA. Molecules. (2018) 23:2555. doi: 10.3390/molecules23102555

54. Shimbo T, Wade PA. Proteins That Read DNA Methylation. Adv Exp Med Biol. (2016)303-20. doi: 10.1007/978-3-319-43624-1_13

55. Tahiliani M, Koh KP, Shen Y, Pastor WA, Bandukwala H, Brudno $\mathrm{Y}$, et al. Conversion of 5-methylcytosine to 5-hydroxymethylcytosine in mammalian DNA by MLL partner TET1. Science. (2009) 324:9305. doi: 10.1126/science.1170116

56. Shi D-Q, Ali I, Tang J, Yang W-C. New insights into 5hmC DNA modification: generation, distribution and function. Front Genet. (2017) 8:100. doi: $10.3389 /$ fgene.2017.00100

57. Hahn MA, Szabó PE, Pfeifer GP. 5-Hydroxymethylcytosine: a stable or transient DNA modification? Genomics. (2014) 104:314-23. doi: 10.1016/j.ygeno.2014.08.015

58. Sallusto F, Lanzavecchia A. Efficient presentation of soluble antigen by cultured human dendritic cells is maintained by granulocyte/macrophage colony-stimulating factor plus interleukin 4 and downregulated by tumor necrosis factor alpha. J Exp Med. (1994) 179:1109-18.

59. Kiertscher SM, Roth MD. Human CD14+ leukocytes acquire the phenotype and function of antigen-presenting dendritic cells when cultured in GM-CSF and IL-4. J Leukoc Biol. (1996) 59:208-218.

60. Inaba K, Steinman RM, Pack MW, Aya H, Inaba M, Sudo T, et al. Identification of proliferating dendritic cell precursors in mouse blood. J Exp Med. (1992) 175:1157-67.

61. Obermajer N, Muthuswamy R, Lesnock J, Edwards RP, Kalinski P. Positive feedback between PGE2 and COX2 redirects the differentiation of human dendritic cells toward stable myeloid-derived suppressor cells. Blood. (2011) 118:5498-505. doi: 10.1182/blood-2011-07-365825

62. Vento-Tormo R, Company C, Rodríguez-Ubreva J, de la Rica L, Urquiza JM, Javierre BM, et al. IL-4 orchestrates STAT6-mediated DNA demethylation leading to dendritic cell differentiation. Genome Biol. (2016) 17:4. doi: 10.1186/s13059-015-0863-2

63. Rodríguez-Ubreva J, Català-Moll F, Obermajer N, Álvarez-Errico D, Ramirez RN, Company C, et al. Prostaglandin E2 leads to the acquisition of DNMT3A-dependent tolerogenic functions in human myeloid-derived suppressor cells. Cell Rep. (2017) 21:154-67. doi: 10.1016/j.celrep.2017.09.018

64. Zhang X, Ulm A, Somineni HK, Oh S, Weirauch MT, Zhang H$\mathrm{X}$, et al. DNA methylation dynamics during ex vivo differentiation and maturation of human dendritic cells. Epigenet Chromat. (2014) 7:21. doi: 10.1186/1756-8935-7-21

65. Pacis A, Tailleux L, Morin AM, Lambourne J, MacIsaac JL, Yotova V, et al. Bacterial infection remodels the DNA methylation landscape of human dendritic cells. Genome Res. (2015) 25:1801-11. doi: 10.1101/gr. 192005.115

66. Bannister AJ, Kouzarides T. Regulation of chromatin by histone modifications. Cell Res. (2011) 21:381-95. doi: 10.1038/cr.2011.22

67. Shlyueva D, Stampfel G, Stark A. Transcriptional enhancers: from properties to genome-wide predictions. Nat Rev Genet. (2014) 15:27286. doi: $10.1038 / \operatorname{nrg} 3682$

68. Creyghton MP, Cheng AW, Welstead GG, Kooistra T, Carey BW, Steine EJ, et al. Histone H3K27ac separates active from poised enhancers and predicts developmental state. Proc Natl Acad Sci USA. (2010) 107:219316. doi: 10.1073/pnas.1016071107

69. Zhu Y, Sun L, Chen Z, Whitaker JW, Wang T, Wang W. Predicting enhancer transcription and activity from chromatin modifications. Nucleic Acids Res. (2013) 41:10032-43. doi: 10.1093/nar/gkt826

70. Zentner GE, Scacheri PC. The chromatin fingerprint of gene enhancer elements. J Biol Chem. (2012) 287:30888-96. doi: 10.1074/jbc.R111. 296491

71. Yadav T, Quivy J-P, Almouzni G. Chromatin plasticity: a versatile landscape that underlies cell fate and identity. Science. (2018) 361:13326. doi: $10.1126 /$ science.aat 8950

72. Di Pietro A, Good-Jacobson KL. Disrupting the code: epigenetic dysregulation of lymphocyte function during infectious disease and lymphoma development. J Immunol. (2018) 201:110918. doi: $10.4049 /$ jimmunol.1800137 
73. Araki Y, Mimura T. The histone modification code in the pathogenesis of autoimmune diseases. Mediators Inflamm. (2017) 2017:2608605. doi: 10.1155/2017/2608605

74. Krawczyk CM, Holowka T, Sun J, Blagih J, Amiel E, DeBerardinis RJ, et al. Toll-like receptor-induced changes in glycolytic metabolism regulate dendritic cell activation. Blood. (2010) 115:4742-9. doi: 10.1182/blood-2009-10-249540

75. Everts B, Amiel E, Huang SC-C, Smith AM, Chang C-H, Lam WY, et al. TLRdriven early glycolytic reprogramming via the kinases TBK1-IKK $\varepsilon$ supports the anabolic demands of dendritic cell activation. Nat Immunol. (2014) 15:323-32. doi: 10.1038/ni.2833

76. Du X, Wen J, Wang Y, Karmaus PWF, Khatamian A, Tan H, et al. Hippo/Mst signalling couples metabolic state and immune function of CD8 $\alpha+$ dendritic cells. Nature. (2018) 558:141-5. doi: 10.1038/s41586-018-0177-0

77. Boukhaled GM, Cordeiro B, Deblois G, Dimitrov V, Bailey SD, Holowka $\mathrm{T}$, et al. The transcriptional repressor polycomb group factor 6, PCGF6, negatively regulates dendritic cell activation and promotes quiescence. Cell Rep. (2016) 16:1829-37. doi: 10.1016/j.celrep.2016.07.026

78. Ding W, Smulan LJ, Hou NS, Taubert S, Watts JL, Walker AK. s-Adenosylmethionine levels govern innate immunity through distinct methylation-dependent pathways. Cell Metab. (2015) 22:633-45. doi: 10.1016/j.cmet.2015.07.013

79. Liu P-S, Wang H, Li X, Chao T, Teav T, Christen S, et al. $\alpha$-ketoglutarate orchestrates macrophage activation through metabolic and epigenetic reprogramming. Nat Immunol. (2017) 18:985-94. doi: 10.1038/ni.3796

80. Xiao $\mathrm{M}$, Yang $\mathrm{H}, \mathrm{Xu} \mathrm{W}, \mathrm{Ma} \mathrm{S}$, Lin $\mathrm{H}$, Zhu $\mathrm{H}$, et al. Inhibition of $\alpha-\mathrm{KG}-$ dependent histone and DNA demethylases by fumarate and succinate that are accumulated in mutations of FH and SDH tumor suppressors. Genes Dev. (2012) 26:1326-38. doi: 10.1101/gad.191056.112

81. Chowdhury R, Yeoh KK, Tian Y, Hillringhaus L, Bagg EA, Rose NR, et al. The oncometabolite 2-hydroxyglutarate inhibits histone lysine demethylases. EMBO Rep. (2011) 12:463-9. doi: 10.1038/embor.2011.43

82. Galdieri L, Vancura A. Acetyl-CoA carboxylase regulates global histone acetylation. J Biol Chem. (2012) 287:23865-76. doi: 10.1074/jbc.M112.380519

83. Vogelauer M, Krall AS, McBrian MA, Li J-Y, Kurdistani SK. Stimulation of histone deacetylase activity by metabolites of intermediary metabolism. J Biol Chem. (2012) 287:32006-16. doi: 10.1074/jbc.M112.362467

84. Preyat N, Leo O. Sirtuin deacylases: a molecular link between metabolism and immunity. J Leukoc Biol. (2013) 93:669-80. doi: 10.1189/jlb.1112557

85. Liu TF, Vachharajani VT, Yoza BK, McCall CE. NAD+-dependent sirtuin 1 and 6 proteins coordinate a switch from glucose to fatty acid oxidation during the acute inflammatory response. J Biol Chem. (2012) 287:2575869. doi: 10.1074/jbc.M112.362343

86. Liu TF, Yoza BK, El Gazzar M, Vachharajani VT, McCall CE. NAD+-dependent SIRT1 deacetylase participates in epigenetic reprogramming during endotoxin tolerance. J Biol Chem. (2011) 286:9856-64. doi: 10.1074/jbc.M110.196790

87. Li M, van Esch BCAM, Wagenaar GTM, Garssen J, Folkerts G, Henricks PAJ. Pro- and anti-inflammatory effects of short chain fatty acids on immune and endothelial cells. Eur J Pharmacol. (2018) 831:529. doi: 10.1016/j.ejphar.2018.05.003

88. Chang PV, Hao L, Offermanns S, Medzhitov R. The microbial metabolite butyrate regulates intestinal macrophage function via histone deacetylase inhibition. Proc Natl Acad Sci USA. (2014) 111:2247-52.

89. Doñas C, Carrasco M, Fritz M, Prado C, Tejón G, Osorio-Barrios F, et al. The histone demethylase inhibitor GSK-J4 limits inflammation through the induction of a tolerogenic phenotype on DCs. J Autoimmun. (2016) 75:105-17. doi: 10.1016/j.jaut.2016.07.011

90. Kuo C-H, Yang S-N, Tsai Y-G, Hsieh C-C, Liao W-T, Chen L-C, et al. Longacting $\beta 2$-adrenoreceptor agonists suppress type 1 interferon expression in human plasmacytoid dendritic cells via epigenetic regulation. Pulm Pharmacol Ther. (2018) 48:37-45. doi: 10.1016/j.pupt.2017.10.004

91. Jin J, Xie X, Xiao Y, Hu H, Zou Q, Cheng X, et al. Epigenetic regulation of the expression of Il12 and Il23 and autoimmune inflammation by the deubiquitinase Trabid. Nat Immunol. (2016) 17:259-68. doi: 10.10 38/ni.3347

92. Cook PC, Owen H, Deaton AM, Borger JG, Brown SL, Clouaire T, et al. A dominant role for the methyl-CpG-binding protein Mbd2 in controlling Th2 induction by dendritic cells. Nat Commun. (2015) 6:6920. doi: $10.1038 /$ ncomms7920

93. Villagra A, Cheng F, Wang H-W, Suarez I, Glozak M, Maurin M, et al. The histone deacetylase HDAC11 regulates the expression of interleukin 10 and immune tolerance. Nat Immunol. (2009) 10:92-100. doi: 10.1038/ni.1673

94. Ptaschinski C, Mukherjee S, Moore ML, Albert M, Helin K, Kunkel SL, et al. RSV-induced H3K4 demethylase KDM5B leads to regulation of dendritic cell-derived innate cytokines and exacerbates pathogenesis in vivo. PLoS Pathog. (2015) 11:e1004978. doi: 10.1371/journal.ppat.1004978

95. Zhang Q, Zhao K, Shen Q, Han Y, Gu Y, Li X, et al. Tet2 is required to resolve inflammation by recruiting Hdac2 to specifically repress IL-6. Nature. (2015) 525:389-93. doi: 10.1038/nature15252

96. Fang TC, Schaefer U, Mecklenbrauker I, Stienen A, Dewell S, Chen $\mathrm{MS}$, et al. Histone $\mathrm{H} 3$ lysine 9 di-methylation as an epigenetic signature of the interferon response. J Exp Med. (2012) 209:66169. doi: 10.1084/jem.20112343

97. Cieślik M, Bekiranov S. Genome-wide predictors of NF-кB recruitment and transcriptional activity. BioData Min. (2015) 8:37. doi: 10.1186/s13040-015-0071-3

98. Smale ST, Tarakhovsky A, Natoli G. Chromatin contributions to the regulation of innate immunity. Annu Rev Immunol. (2014) 32:489-511. doi: 10.1146/annurev-immunol-03 1210-101303

99. Dissanayake D, Hall H, Berg-Brown N, Elford AR, Hamilton SR, Murakami $\mathrm{K}$, et al. Nuclear factor- $\kappa \mathrm{B} 1$ controls the functional maturation of dendritic cells and prevents the activation of autoreactive T cells. Nat Med. (2011) 17:1663-7. doi: 10.1038/nm.2556

100. Smith MA, Wright G, Wu J, Tailor P, Ozato K, Chen X, et al. Positive regulatory domain I (PRDM1) and IRF8/PU.1 counter-regulate MHC class II transactivator (CIITA) expression during dendritic cell maturation. J Biol Chem. (2011) 286:7893-904. doi: 10.1074/jbc.M110.165431

101. Meredith MM, Liu K, Darrasse-Jeze G, Kamphorst AO, Schreiber HA, Guermonprez P, et al. Expression of the zinc finger transcription factor zDC (Zbtb46, Btbd4) defines the classical dendritic cell lineage. J Exp Med. (2012) 209:1153-65. doi: 10.1084/jem.20112675

102. Ardouin L, Luche H, Chelbi R, Carpentier S, Shawket A, Montanana Sanchis F, et al. Broad and largely concordant molecular changes characterize tolerogenic and immunogenic dendritic cell maturation in thymus and periphery. Immunity. (2016) 45:305-18. doi: 10.1016/j.immuni.2016. 07.019

103. Seguín-Estévez Q, Dunand-Sauthier I, Lemeille S, Iseli C, Ibberson M, Ioannidis V, et al. Extensive remodeling of DC function by rapid maturationinduced transcriptional silencing. Nucleic Acids Res. (2014) 42:964155. doi: 10.1093/nar/gku674

104. Satpathy AT, Wumesh KC, Albring JC, Edelson BT, Kretzer NM, Bhattacharya D, et al. Zbtb46expression distinguishes classical dendritic cells and their committed progenitors from other immune lineages. J Exp Med. (2012) 209:1135-52. doi: 10.1084/jem.20120030

105. Wang H, Wang L, Erdjument-Bromage H, Vidal M, Tempst P, Jones RS, et al. Role of histone H2A ubiquitination in polycomb silencing. Nature. (2004) 431:873-8. doi: 10.1038/nature02985

106. Wheaton K, Sarkari F, Stanly Johns B, Davarinejad H, Egorova O, Kaustov L, et al. UbE2E1/UBCH6 is a critical in vivo E2 for the PRC1catalyzed ubiquitination of H2A at Lys-119. J Biol Chem. (2017) 292:2893902. doi: 10.1074/jbc.M116.749564

107. Akasaka T, Takahashi N, Suzuki M, Koseki H, Bodmer R, Koga H. MBLR, a new RING finger protein resembling mammalian Polycomb gene products, is regulated by cell cycle-dependent phosphorylation. Genes Cells. (2002) 7:835-50.

108. Ogawa H, Ishiguro K-I, Gaubatz S, Livingston DM, Nakatani Y. A complex with chromatin modifiers that occupies E2F- and Myc-responsive genes in G0 cells. Science. (2002) 296:1132-6. doi: 10.1126/science.1069861

109. Stielow B, Finkernagel F, Stiewe T, Nist A, Suske G. MGA, L3MBTL2 and E2F6 determine genomic binding of the noncanonical Polycomb repressive complex PRC1.6. PLoS Genet. (2018) 14:e1007193. doi: 10.1371/journal.pgen.1007193

110. Lee MG, Norman J, Shilatifard A, Shiekhattar R. Physical and functional association of a trimethyl $\mathrm{H} 3 \mathrm{~K} 4$ demethylase 
and Ring6a/MBLR, a polycomb-like protein. Cell. (2007) 128:877-87. doi: 10.1016/j.cell.2007.02.004

111. Qin J, Whyte WA, Anderssen E, Apostolou E, Chen H-H, Akbarian S, et al. The polycomb group protein L3mbtl2 assembles an atypical PRC1-family complex that is essential in pluripotent stem cells and early development. Cell Stem Cell. (2012) 11:319-32. doi: 10.1016/j.stem.2012.06.002

112. Iwase S, Lan F, Bayliss P, de la Torre-Ubieta L, Huarte M, Qi HH, et al. The X-linked mental retardation gene SMCX/JARID1C defines a family of histone H3 lysine 4 demethylases. Cell. (2007) 128:107788. doi: 10.1016/j.cell.2007.02.017

113. D'Andrea A, Aste-Amezaga M, Valiante NM, Ma X, Kubin M, Trinchieri G. Interleukin 10 (IL-10) inhibits human lymphocyte interferon gammaproduction by suppressing natural killer cell stimulatory factor/IL-12 synthesis in accessory cells. J Exp Med. (1993) 178:1041-8.

114. Yao Y, Li W, Kaplan MH, Chang C-H. Interleukin (IL)-4 inhibits IL-10 to promote IL-12 production by dendritic cells. J Exp Med. (2005) 201:18991903. doi: $10.1084 /$ jem.20050324

115. Kuo C-H, Lin C-H, Yang S-N, Huang M-Y, Chen H-L, Kuo P-L, et al. Effect of prostaglandin I2 analogs on cytokine expression in human myeloid dendritic cells via epigenetic regulation. Mol Med. (2012) 18:43344. doi: 10.2119/molmed.2011.00193

116. Kuo C-H, Yang S-N, Kuo H-F, Lee M-S, Huang M-Y, Huang S-K, et al. Cysteinyl leukotriene receptor antagonist epigenetically modulates cytokine expression and maturation of human myeloid dendritic cells. Pulm Pharmacol Ther. (2016) 39:28-37. doi: 10.1016/j.pupt.2016.06.001

117. Quintin J. Fungal mediated innate immune memory, what have we learned? Semin Cell Dev Biol. (2019) 89:71-7. doi: 10.1016/j.semcdb.2018.05.023

118. Fallarino F, Pallotta MT, Matino D, Gargaro M, Orabona C, Vacca $\mathrm{C}$, et al. LPS-conditioned dendritic cells confer endotoxin tolerance contingent on tryptophan catabolism. Immunobiology. (2015) 220:31521. doi: 10.1016/j.imbio.2014.09.017

119. Arts RJW, Carvalho A, La Rocca C, Palma C, Rodrigues F, Silvestre R, et al. Immunometabolic pathways in bcg-induced trained immunity. Cell Rep. (2016) 17:2562-71. doi: 10.1016/j.celrep.2016.11.011

120. Kaufmann E, Sanz J, Dunn JL, Khan N, Mendonça LE, Pacis A, et al. BCG educates hematopoietic stem cells to generate protective innate immunity against tuberculosis. Cell. (2018) 172:176-90.e19. doi: 10.1016/j.cell.2017.12.031

121. Cheng S-C, Quintin J, Cramer RA, Shepardson KM, Saeed S, Kumar V, et al. mTOR- and HIF-1 $\alpha$-mediated aerobic glycolysis as metabolic basis for trained immunity. Science. (2014) 345:1250684. doi: 10.1126/science.1250684

122. Wendeln A-C, Degenhardt K, Kaurani L, Gertig M, Ulas T, Jain G, et al. Innate immune memory in the brain shapes neurological disease hallmarks. Nature. (2018) 556:332-8. doi: 10.1038/s41586-018-0023-4

123. Arts RJW, Novakovic B, Ter Horst R, Carvalho A, Bekkering S, Lachmandas E, et al. Glutaminolysis and fumarate accumulation integrate immunometabolic and epigenetic programs in trained immunity. Cell Metab. (2016) 24:807-19. doi: 10.1016/j.cmet.2016.10.008

124. Bekkering S, Arts RJW, Novakovic B, Kourtzelis I, van der Heijden CDCC, Li Y, et al. Metabolic induction of trained immunity through the mevalonate pathway. Cell. (2018) 172:135-46.e9. doi: 10.1016/j.cell. 2017.11.025

125. Ma S, Wan X, Deng Z, Shi L, Hao C, Zhou Z, et al. Epigenetic regulator CXXC5 recruits DNA demethylase Tet2 to regulate TLR7/9-elicited IFN response in pDCs. J Exp Med. (2017) 214:1471-91. doi: 10.1084/jem.20161149

126. Wilson VL, Smith RA, Ma S, Cutler RG. Genomic 5-methyldeoxycytidine decreases with age. J Biol Chem. (1987) 262:9948-9951.

127. Gowers IR, Walters K, Kiss-Toth E, Read RC, Duff GW, Wilson AG. Agerelated loss of $\mathrm{CpG}$ methylation in the tumour necrosis factor promoter. Cytokine. (2011) 56:792-7. doi: 10.1016/j.cyto.2011.09.009

128. Sullivan KE, Reddy ABM, Dietzmann K, Suriano AR, Kocieda VP, Stewart $\mathrm{M}$, et al. Epigenetic regulation of tumor necrosis factor alpha. Mol Cell Biol. (2007) 27:5147-60. doi: 10.1128/MCB.02429-06

129. van Rietschoten JGI, Gal-Yam EN, Jeong S, Cortez CC, Verweij CL, Jones PA. Epigenetic regulation and nucleosome positioning in the human TATA-less IL-1 alpha promoter. Genes Immun. (2008) 9:58290. doi: 10.1038/gene.2008.53

130. Wei L, Liu B, Tuo J, Shen D, Chen P, Li Z, et al. Hypomethylation of the IL17RC promoter associates with age-related macular degeneration. Cell Rep. (2012) 2:1151-8. doi: 10.1016/j.celrep.2012.10.013

131. Lepeule J, Baccarelli A, Motta V, Cantone L, Litonjua AA, Sparrow $\mathrm{D}$, et al. Gene promoter methylation is associated with lung function in the elderly: the Normative Aging Study. Epigenetics. (2012) 7:2619. doi: 10.4161/epi.7.3.19216

132. El Mezayen R, El Gazzar M, Myer R, High KP. Aging-dependent upregulation of IL-23p19 gene expression in dendritic cells is associated with differential transcription factor binding and histone modifications. Aging Cell. (2009) 8:553-65. doi: 10.1111/j.1474-9726.2009.00502.x

133. Dearman RJ, Betts CJ, Beresford L, Bailey L, Caddick HT, Kimber I. Butyl benzyl phthalate: effects on immune responses to ovalbumin in mice. J Appl Toxicol. (2009) 29:118-25. doi: 10.1002/jat.1388

134. Kuo C-H, Hsieh C-C, Kuo H-F, Huang M-Y, Yang S-N, Chen L-C, et al. Phthalates suppress type I interferon in human plasmacytoid dendritic cells via epigenetic regulation. Allergy. (2013) 68:870-9. doi: 10.1111/ all.12162

135. Wong CP, Rinaldi NA, Ho E. Zinc deficiency enhanced inflammatory response by increasing immune cell activation and inducing IL6 promoter demethylation. Mol Nutr Food Res. (2015) 59:991-9. doi: 10.1002/mnfr.201400761

136. Jeong Y-J, Hong S-W, Kim J-H, Jin D-H, Kang JS, Lee WJ, et al. Vitamin C-treated murine bone marrow-derived dendritic cells preferentially drive naïve $\mathrm{T}$ cells into Th1 cells by increased IL-12 secretions. Cell Immunol. (2011) 266:192-9. doi: 10.1016/j.cellimm.2010.10.005

137. Blaschke K, Ebata KT, Karimi MM, Zepeda-Martínez JA, Goyal P, Mahapatra S, et al. Vitamin C induces Tet-dependent DNA demethylation and a blastocyst-like state in ES cells. Nature. (2013) 500:222-6. doi: 10.1038/nature12362

138. Shenoy N, Bhagat T, Nieves E, Stenson M, Lawson J, Choudhary GS, et al. Upregulation of TET activity with ascorbic acid induces epigenetic modulation of lymphoma cells. Blood Cancer J. (2017) 7:e587. doi: 10.1038/bcj.2017.65

139. Romani M, Pistillo MP, Banelli B. Environmental epigenetics: crossroad between public health, lifestyle, and cancer prevention. Biomed Res Int. (2015) 2015:587983. doi: 10.1155/2015/587983

140. Madej D, Borowska K, Bylinowska J, Szybalska A, Pietruszka B. Dietary intakes of iron and zinc assessed in a selected group of the elderly: are they adequate? Rocz Panstw Zakl Hig. (2013) 64:97-104.

141. Haase H, Rink L. The immune system and the impact of zinc during aging. Immun Ageing. (2009) 6:9. doi: 10.1186/1742-4933-6-9

142. Baylis D, Bartlett DB, Patel HP, Roberts HC. Understanding how we age: insights into inflammaging. Longev Healthspan. (2013) 2:8. doi: $10.1186 / 2046-2395-2-8$

143. Jasiulionis MG. Abnormal epigenetic regulation of immune system during aging. Front Immunol. (2018) 9:197. doi: 10.3389/fimmu.2018.00197

144. De Angulo A, Faris R, Daniel B, Jolly C, deGraffenried L. Age-related increase in IL-17 activates pro-inflammatory signaling in prostate cells. Prostate. (2015) 75:449-62. doi: 10.1002/pros.22931

145. Tabarkiewicz J, Pogoda K, Karczmarczyk A, Pozarowski P, Giannopoulos K. The role of IL-17 and Th17 lymphocytes in autoimmune diseases. Arch Immunol Ther Exp. (2015) 63:435-49.

146. Cua DJ, Sherlock J, Chen Y, Murphy CA, Joyce B, Seymour B, et al. Interleukin-23 rather than interleukin-12 is the critical cytokine for autoimmune inflammation of the brain. Nature. (2003) 421:7448. doi: $10.1038 /$ nature 01355

147. O'Hagan HM, Wang W, Sen S, Destefano Shields C, Lee SS, Zhang YW, et al. Oxidative damage targets complexes containing DNA methyltransferases, SIRT1, and polycomb members to promoter CpG Islands. Cancer Cell. (2011) 20:606-19. doi: 10.1016/j.ccr.2011.09.012

148. Qiu Y, Zhu Y, Yu H, Yi S, Su W, Cao Q, et al. Ocular Behcet's disease is associated with aberrant methylation of interferon regulatory factor 8 (IRF8) in monocyte-derived dendritic cells. Oncotarget. (2017) 8:5127787. doi: 10.18632/oncotarget.17235 
149. Qiu Y, Yu H, Zhu Y, Ye Z, Deng J, Su W, et al. Hypermethylation of Interferon Regulatory Factor 8 (IRF8) confers risk to vogt-koyanagiharada disease. Sci Rep. (2017) 7:1007. doi: 10.1038/s41598-01701249-7

150. Zhou J-J, Wang G-S, Li X-P, Li X-M, Qian L. [Activation of hypomethylated DNA on plasmacytoid dendritic cells in patients with systemic lupus erythematosus]. Zhonghua Yi Xue Za Zhi. (2013) 93:3119-21.

151. Lockett GA, Patil VK, Soto-Ramírez N, Ziyab AH, Holloway JW, Karmaus W. Epigenomics and allergic disease. Epigenomics. (2013) 5:68599. doi: 10.2217/epi.13.68

152. Nakano H, Burgents JE, Nakano K, Whitehead GS, Cheong C, Bortner $\mathrm{CD}$, et al. Migratory properties of pulmonary dendritic cells are determined by their developmental lineage. Mucosal Immunol. (2013) 6:67891. doi: $10.1038 / \mathrm{mi} .2012 .106$

153. Moran TP, Nakano H, Kondilis-Mangum HD, Wade PA, Cook DN. Epigenetic control of Ccr7 expression in distinct lineages of lung dendritic cells. J Immunol. (2014) 193:4904-13. doi: 10.4049/jimmunol. 1401104

154. Fedulov AV, Kobzik L. Allergy risk is mediated by dendritic cells with congenital epigenetic changes. Am J Respir Cell Mol Biol. (2011) 44:285-92. doi: $10.1165 / \mathrm{rcmb} .2009-0400 \mathrm{OC}$
155. Mikhaylova L, Zhang Y, Kobzik L, Fedulov AV. Link between epigenomic alterations and genome-wide aberrant transcriptional response to allergen in dendritic cells conveying maternal asthma risk. PLOS ONE. (2013) 8:e70387. doi: 10.1371/journal.pone.0070387

156. Arrigoni L, Al-Hasani H, Ramírez F, Panzeri I, Ryan DP, Santacruz D, et al. RELACS nuclei barcoding enables high-throughput ChIP-seq. Commun Biol. (2018) 1:214. doi: 10.1038/s42003-018-0219-z

157. Skene PJ, Henikoff JG, Henikoff S. Targeted in situ genome-wide profiling with high efficiency for low cell numbers. Nature Protocols. (2018) 13:100619. doi: $10.1038 /$ nprot.2018.015

Conflict of Interest Statement: The authors declare that the research was conducted in the absence of any commercial or financial relationships that could be construed as a potential conflict of interest.

Copyright $\odot 2019$ Boukhaled, Corrado, Guak and Krawczyk. This is an open-access article distributed under the terms of the Creative Commons Attribution License (CC $B Y)$. The use, distribution or reproduction in other forums is permitted, provided the original author(s) and the copyright owner(s) are credited and that the original publication in this journal is cited, in accordance with accepted academic practice. No use, distribution or reproduction is permitted which does not comply with these terms. 